\title{
ОСОБЛИВОСТІ МОРФО-ФУНКЦІОНАЛЬНОГО СТАНУ ОРГАНІВ СЕЧОВИДІЛЬНОЇ СИСТЕМИ ПЛОДІВ ТА НОВОНАРОДЖЕНИХ ВІД МАТЕРІВ 3 УСКЛАДНЕНОЮ ВАГІТНІСТЮ
}

\author{
Мирошниченко М. С., Капустник Н. В.
}

\section{ВСТУП}

Здоров'я дітей - це майбутнє нації і найбільш важливий ресурс будь-якого суспільства ${ }^{1}$. Наразі стан здоров'я дітей в Україні $\epsilon$ незадовільним i має сталу тенденцію до зростання рівня захворюваності, поширеності хвороб та інвалідизації $2,3,4,5$. Патологія органів сечовидільної системи (далі - ОСВС) дитячого населення України $\epsilon$ серйозною і значимою проблемою сучасної педіатрії ${ }^{6}$ зв'язку з високим рівнем поширеності, ризиком розвитку ускладнень та інвалідизації. Протягом останніх років у структурі дитячої

${ }^{1}$ Дудіна О. О., Терещенко А. В. Ситуаційний аналіз стану здоров'я дитячого населення. Вісник соціальної гігієни та організації охорони здоров'я України. 2014. № 2 (60). C. 49-57.

2 Щорічна доповідь про стан здоров'я населення, санітарно-епідемічну ситуацію та результати діяльності системи охорони здоров'я України. 2013 рік / Український інститут стратегічних досліджень Міністерства охорони здоров'я України ; за ред. О. С. Мусія та ін. Київ, 2014. 438 с.

${ }^{3}$ Щорічна доповідь про стан здоров'я населення, санітарно-епідемічну ситуацію та результати діяльності системи охорони здоров'я України. 2014 рік / Український інститут стратегічних досліджень Міністерства охорони здоров'я України ; за ред. О. М. Квіташвілі та ін. Київ, 2015. 460 с.

${ }^{4}$ Щорічна доповідь про стан здоров'я населення, санітарно-епідемічну ситуацію та результати діяльності системи охорони здоров'я України. 2015 рік / Український інститут стратегічних досліджень Міністерства охорони здоров'я України ; за ред. В. В. Шафранського. Київ, 2016. 452 с.

${ }^{5}$ Щорічна доповідь про стан здоров'я населення, санітарно-епідемічну ситуацію та результати діяльності системи охорони здоров'я України. 2016 рік / Український інститут стратегічних досліджень Міністерства охорони здоров'я України ; за ред. П. С. Мельника та ін. Київ : Коломіцин В. Ю., 2017. 516 с.

6 Антипкін Ю. Г., Волосовець О. П., Майданник В. Г., Березенко В. С., Моісеєнко Р. О., Виговська О. В. та ін. Стан здоров'я дитячого населення майбутнє країни (частина 1). Здоровье ребенка. 2018. № 13 (1). С. 1-11. DOI 10.22141/2224-0551.13.1.2018.127059. 
захворюваності патологія ОСВС посідає 9-10-е місця, і на неї припадає $1,97-2,2 \%{ }^{7}$.

Переважна більшість захворювань ОСВС у дітей має свої витоки в антенатальному або інтранатальному періодах розвитку. Відомо, що ушкодження органів цієї системи, що виникли антенатально, можуть проявлятися не відразу після народження, а через роки й навіть десятиліття $^{8,9}$. Захворювання матері, ускладнення під час вагітностей та пологів виступають основними факторами, що призводять до ушкодження ОСВС плодів та новонароджених ${ }^{10}$.

Метою роботи є, по-перше, аналіз даних літератури щодо впливу патології матері, ускладнень під час вагітностей та пологів на морфологічний стан ОСВС дітей; по-друге, викладення основних результатів проведеного комплексного морфологічного дослідження аутопсійного й експериментального матеріалу щодо визначення морфофункціональних особливостей та механізмів розвитку структурних змін у нирках, сечоводах, сечовому міхурі плодів та новонароджених від матерів з ускладненою вагітністю.

\section{1. Вплив патології матері, ускладнень під час перебігу вагітностей \\ і в пологах на морфо-функціональний стан органів сечовидільної системи плодів і новонароджених (аналіз даних літератури)}

Жоден патологічний стан антенатального, інтранатального або постнатального періодів не залишає інтактними нирки як головний елімінуючий орган ${ }^{11}$.

Давно відомий факт наявності зв'язку між патологією однойменних органів матері й плода. Виявлено, що частота нефропатій у дітей із сімей 3

${ }^{7}$ Щорічна доповідь про стан здоров'я населення, санітарно-епідемічну ситуацію та результати діяльності системи охорони здоров'я України. 2016 рік / Український інститут стратегічних досліджень Міністерства охорони здоров'я України ; за ред. П. С. Мельника та ін. Київ : Коломіцин В. Ю., 2017. 516 с.

8 Чугунова О. Л., Панова Л. Д. Факторы риска и диагностика заболеваний органов мочевой системы у новорожденных детей. Российский вестник перинатологии и педиатрии. 2010. № 1. С. 12-20.

${ }^{9}$ Ingelfinger J. R., Kalantar-Zadeh K., Schaefer F. World kidney day 2016: averting the legacy of kidney disease - focus on childhood. Pediatr Nephrol. 2016. № 31 (3). P. 343-348. DOI 10.1111/jorc.12148.

${ }^{10}$ Островский И. М., Прохоров Е. В., Нарижный М. Ю. Здоровье детей по результатам анкетирования родителей. Российский вестник перинатологии и педиатрии. 2017. № 62 (3). С. 105-111. DOI 10.21508/1027-4065-2017-62-3-105-111.

${ }^{11}$ Иванова И. Е., Яшина Е. В. Особенности мочевого синдрома у грудных детей, перенесших гипоксически-ишемические состояния в перинатальнои периоде. Здравоохранение Чувашии. 2012. № 3. С. 34-38. 
патологією нирок у 20 разів вища, ніж у загальній популяції ${ }^{2}$. Доведений зв'язок хвороб нирок матері з вадами розвитку ОСВС плода ${ }^{13}$.

У жінок з патологією нирок визначені високі рівні ренальних антитіл, які трансплацентарно проникають до плода й впливають на формування його імунного статусу й на розвиток $\mathrm{OCBC}^{14}$.

Серед різноманіття несприятливих факторів, що впливають на організм плода й новонародженого, вагома роль належить гіпоксії, зумовленій розвитком у матері ускладнень під час вагітностей або в пологах ${ }^{15}$. Відмічено, що порушення функцій нирок після перенесеного гіпоксичного впливу зустрічаються в $70-80 \%$ випадків ${ }^{16}$. При легкому ступені гіпоксичного ураження нирок у новонароджених розвивається гіпоксична нефропатія, або ішемічна нефропатія, а при більш вираженому впливі - інтерстиційний нефрит та інфаркт нирок, що часто супроводжується гострою нирковою недостатністю ${ }^{17}$.

Гіпоксичні процеси, основою яких $є$ порушення метаболізму, сприяють утворенню в тканинах активних форм кисню, розвитку енергетичної недостатності, ведуть до прискорення процесів перекисного окиснення структур і пошкодження мембран клітин. При гіпоксії система антиоксидантного захисту внаслідок зниження своїх функцій не справляється з нейтралізацією активних форм кисню, що, в свою чергу, спричиняє вторинне ураження ліпідного шару мембран i клітинних структур ${ }^{18}$.

12 Панова Л. Д., Ахмадеева Э. Н. Патология почек в системе мать-плодноворожденный. Медицинский вестник Башкортостана. 2007. № 2 (1). С. 37-41.

13 Иванов Д. О., Петренко Ю. В., Шемякина О. О., Фот А. Ю. Анализ антенатальных факторов риска формирования врожденных пороков внутренних органов у детей. Трансляцчионная медицина. 2012. № 1 (12). С. 61-68.

${ }^{14}$ Генералова Г. А., Алимова Е. Ю., Якунина Н. А. Роль эпигенетических факторов в формировании аномалий органов мочевой системы у детей. Современные технологии 8 педиатрии и детской хирургии: материалы IV Российского конгресса. Москва, 2005. с. 183.

15 Зеленцова В. Л., Шилко В. И., Медведева С. Ю. Морфологические особенности почек у плодов и новорожденных, перенесших гипоксию. Архив патологии. 2003. № 6. С. 40-44.

16 Попов С. В., Облазницкий В. Н. Особенности нарушения функций мочевыделительной системы у новорожденных с гипоксическим поражением ЦНС тяжелой степени. Вісник СумДУ. Серія “Медицина”. 2008. № 2 (2). С. 88-91.

${ }^{17}$ Чугунова О. Л., Шумихина М. В., Думова С. В. Современные представления об инфекции органов мочевой системы у новорожденных и детей раннего возраста. Эффективная фармакотерапия. 2013. № 42. С. 38-47.

18 Аушева Ф. Х., Летифов Г. М. Развитие почек и процессы свободнорадикального окисления у новорожденных и детей раннего возраста, рожденных у матерей с неблагоприятным течением беременности. Педиатрия. 2007. № 86 (6). C. $15-20$. 
У нирках плодів та новонароджених, що розвивалися в умовах хронічної внутрішньоутробної гіпоксії (далі - ХВГ), відзначено зменшення органометричних параметрів, асинхронний розвиток судинного та епітеліального компонентів нефрона, високий відсоток проявів морфологічної незрілості ${ }^{19}$ та дисплазій ${ }^{20,21,22}$, фіброзні зміни, збільшення індексу апоптозу, виражені порушення кровообігу ${ }^{23,24}$.

У дітей $з$ вродженими вадами розвитку ОСВС перенесена ХВГ ускладнює морфо-функціональний стан нирок і призводить до мембранопатологічних змін тубулярного і гломерулярного апарату нефрона ${ }^{25}$.

Гіпоксія та розлади мікроциркуляції в нирковій тканині, які настають внаслідок цього, є одним 3 провідних факторів розвитку інфекційно-запального процесу в нирках ${ }^{26}$. Особливості організму новонародженого сприяють швидкому прогресуванню запального процесу з некротичними та склеротичними змінами в нирковій тканині, які призводять до погіршення функцій цього органу й до розвитку уремії, артеріальної гіпертензії, особливо при розвиткові інфекцій на тлі вад розвитку $\mathrm{OCBC}^{27}$.

19 Зеленцова В. Л., Шилко В. И., Медведева С. Ю. Морфологические особенности почек у плодов и новорожденных, перенесших гипоксию. Архив патологии. 2003. № 6. С. 40-44.

${ }^{20}$ Иванов Д. О., Петренко Ю. В., Шемякина О. О., Фот А. Ю. Анализ антенатальных факторов риска формирования врожденных пороков внутренних органов у детей. Трансляционная медицина. 2012. № 1 (12). С. 61-68.

${ }^{21}$ Hei M. Y., Yi Z. W. Environmental factors for the development of fetal urinary malformations. World J Pediatr. 2014. № 10 (1). P. 17-23. DOI 10.1007/s12519-0140449-1.

22 Зербіно Д. Д., Багрій М. М., Дядик О. О. Судинна патологія нирок. Вінниця : Нова книга, 2015. 456 с.

${ }^{23}$ Tang J., Zhu Z., Xia S., Li N., Chen N., Gao Q. et al. Chronic hypoxia in pregnancy affected vascular tone of renal interlobar arteries in the offspring. Scientific Reports. 2015. № 5 (9723). DOI 10.1038/srep09723.

${ }^{24}$ Яблонь О. С., Задорожна Т. Д., Саврун Т. І., Холод Л. П. Клініко-морфологічні паралелі у дослідженні нирок недоношених новонароджених, які перенесли перинатальну гіпоксію. Современная педиатрия. 2013. № 8 (56). С. 145-149.

${ }^{25}$ Лук'яненко Н. С., Гнатенко О. З., Кенс К. А., Ковалів І. Б., Кеч Н. Р. Фактори формування хронічного захворювання нирок у дітей раннього віку з природженими вадами розвитку нирок. Украӥнський журнал нефрологї та діалізу. 2012. № 3 (35/1). C. $51-55$.

${ }^{26}$ Чугунова О. Л., Шумихина М. В., Думова С. В. Современные представления об инфекции органов мочевой системы у новорожденных и детей раннего возраста. Эффективная фармакотерапия. 2013. № 42. С. 38-47.

27 Чугунова О. Л., Панова Л. Д. Факторы риска и диагностика заболеваний органов мочевой системы у новорожденных детей. Российский вестник перинатологии и педиатрии. 2010. № 1. С. 12-20. 
Гіпоксія на основі морфо-функціональної незрілості нирок є однією 3 причин розвитку дисметаболічної нефропатії в новонароджених ${ }^{28}$.

Важливим критерієм тяжкої гіпоксії $є$ розвиток поліорганної недостатності в новонародженого, що характеризується ураженням центральної нервової системи, легенів, нирок, серця і таке інше. Гіпоксичні ушкодження органів можуть розвиватися одночасно або послідовно: ураження одного органа тягне за собою порушення функцій іншого ${ }^{29}$. Відмічено, що при розвитку синдрому поліорганної недостатності в новонароджених ураження центральної нервової системи є первинним, а ураження ОСВС має вторинний характер ${ }^{30}$.

Актуальне питання постає з проблеми гострого ушкодження нирок у новонароджених, що спричиняє значні порушення гомеостазу 3 розвитком у тяжких випадках термінальної стадії ушкодження гострої ниркової недостатності. Частота гострого ушкодження нирок варіює від $8 \%$ до $24 \%$, а летальність - від $33 \%$ до $78 \%{ }^{31,32}$. Гостре ушкодження нирок у новонародженого обумовлено інтранатальною гіпоксією, тривалими реанімаційними заходами, неадекватним режимом штучної вентиляції легенів ${ }^{33,34}$, затяжними пологами, відшаруванням плаценти ${ }^{35}$.

${ }^{28}$ Безрук В. В. Нефрологічна патологія у дітей підліткового віку Чернівецької області. Вісник проблем біології і медицини. 2014. № 3 (1/110). С. 34-37.

29 Халецкая О. В., Козлова Е. М., Шунькина Г. Л., Булдынская Л. И., Шкалова Л. В. Полиорганность поражения у новорожденных при тяжелой гипоксии. Медицинский альманах. 2007. № 1. С. 84-86.

${ }^{30}$ Нурмагамбетова Б. К. Особенности течения полиорганной недостаточности у доношенных новорожденных. Денсаулькк сактауды дамыту журнальл. 2012. № 1 (2). С. 55-58.

${ }^{31}$ Годованець Ю. Д., Бабінцева А. Г., Нікорич С. І. Гостре пошкодження нирок у новонароджених : невирішені питання діагностики та стратифікації ступеня тяжкості патології. Неонатологія, хірургія та перинатальна медицина. 2014. № IV (3/13). С. 89-94.

32 Аборин С. В., Прилепина М. А. Семиотика острого повреждения почек у недоношенных детей. Национальная ассоциаџия ученых (Медицинские науки). 2015. № IX (14). C. 100-103.

${ }^{33}$ Плотников Е. Ю., Силачев Д. Н., Павленко Т. А., Павлова В. С., Крючко Д. С., Зубков В. В., Зоров Д. Б., Сухих Г. Т. Острое повреждение почек у новорожденных. От эксперимента к клинической практике. Неонатология: новости, мнения, обучение. 2017. № 4. С. 58-63.

${ }^{34}$ Володин Н. Н. Неонатология. Национальное руководство. Москва : ГЭОТАРМедиа, 2013. 896 с.

35 Гельдт В. Г., Кузовлева Г. И. Диагностика пороков мочевыделительной системы у новорожденных и грудных детей. Педиатрия. 2006. № 1. С. 87-94. 
Гостра ниркова недостатність у новонароджених може спричинити хронічну ниркову недостатність у віддаленому віковому періоді ${ }^{36}$.

Для дітей, які перенесли гіпоксично-ішемічний стан у перинатальному періоді, характерні патологічні зміни в аналізах сечі у вигляді ізольованої кристалурії при поєднанні з інфекційно-запальними процесами, які виникли у зв'язку 3 наявністю у матері вогнищ хронічної інфекції у вигляді кристалурії і лейкоцитурії, що можна пов'язати з виникненням вторинної мембранопатології нефроцитів на тлі кисневого голодування і комплексу патофізіологічних змін, які виникають у результаті гіпоксії ${ }^{37}$.

Хронічна плацентарна недостатність спричиняє не лише розвиток ХВГ плода, але й його затримку внутрішньоутробного розвитку $\left(\right.$ далі - ЗВУР) ${ }^{38}$. ЗВУР призводить до зменшення органометричних параметрів нирок плодів і супроводжується такими змінами їхньої гістоструктури: витонченням і нерівномірністю гломерулогенної зони кіркового шару; диспластичними й дистрофічними процесами, що характеризуються наявністю слабко диференційованих гломерул i канальців у дефінітивній зоні; проникненням ембріональних клубочків і ділянок нефрогенної бластеми в глибокі шари кори; розвитком білкової дистрофії епітелію канальців та їх кістоподібної деформації; ознаками порушення кровообігу; збільшенням кількості стромальних елементів ${ }^{39}$. У нирках плодів із ЗВУР виявлено збільшення апоптотичної активності, зниження експресії реніну й ангіотензиногену ${ }^{40}$.

36 Даминова М. А., Сафина А. И., Хамзина Г. А. Морфофункциональные особенности органов мочевой системы у детей, родившихся недоношенными и маловесными. Вестник современной клинической медицины. 2013. № 6 (2). С. 79-86.

${ }^{37}$ Иванова И. Е., Яшина Е. В. Особенности мочевого синдрома у грудных детей, перенесших гипоксически-ишемические состояния в перинатальнои периоде. Здравоохранение Чувашии. 2012. № 3. С. 34-38.

${ }^{38}$ Белоусова Т. В., Андрюшина И. В. Задержка внутриутробного развития и ее влияние на состояние здоровья детей в последующие периоды жизни. Возможности нутритивной коррекции. Вопросы современной педиатрии. 2015. № 14 (1). С. 23-30. DOI 10.15690/vsp.v14i1.1259.

${ }^{39}$ Сисоєнко О. П. Морфологічна характеристика нирок плоду в строку гестації 20-27 тижнів при затримці внутрішньоутробного розвитку : автореф. дис. ... канд. мед. наук : 14.03 .02 ; Луганський державний медичний університет. Луганськ, 2003. $19 \mathrm{c}$.

${ }^{40}$ Wang Y. P., Chen X., Zhang Z. K., Cui H. Y., Wang P., Wang Y. Effects of a restricted fetal growth environment on human kidney morphology, cell apoptosis and gene expression. J Renin Angiotensin Aldosterone Syst. 2015. № 16 (4). P. 1028-1035. DOI 10.1177/1470320314543808. 
ЗВУР плода супроводжується комплексним порушенням показників його уродинаміки. У міру прогресування ЗВУР відзначається зниження резервуарної місткості сечового міхура, збільшення об'єму залишкової сечі й частоти сечовипускань ${ }^{41}$.

Залізодефіцитна анемія (далі - ЗДА) $є$ одним із найбільш поширених ускладнень вагітності, частота якої в різних країнах світу коливається від $21 \%$ до $80 \%$ (за рівнем гемоглобіну) і від $49 \%$ до $99 \%$ (за рівнем сироваткового заліза). ЗДА у вагітних спричиняє розвиток фетоплацентарної недостатності, ХВГ та ЗВУР плода, ускладнює перебіг прееклампсії (далі -ПЕ), збільшує частоту ускладнень під час родового акту і в післяпологовому періоді ${ }^{42}$.

При ЗДА матері в дітей відзначено відставання довжини й ширини нирок, зниження ренального кровотоку ${ }^{43}$.

ЗДА у матері є одною з основних причин розвитку дефіциту заліза й анемії в плодів та новонароджених ${ }^{44}$. Залізо, як відомо, відіграє роль у розвитку нирок. В експерименті на щурах показано, що дефіцит заліза в організмі новонароджених викликає зменшення кількості, щільності й площі клубочків, а також індукує розвиток склерозу в нирках ${ }^{45,46}$.

ПЕ у матері, яка є одним 3 найтяжчих ускладнень вагітності, уповільнює темпи нефрогенезу у плодів, зменшує питомий об'єм (далі - ПО) канальців, збільшує ПО строми і судинного компонента ${ }^{47}$.

${ }^{41}$ Глыбочко П. В., Чехонацкая М. Л., Пискунова Л. В. Состояние уродинамики нижних мочевых путей плода при задержке внутриутробного развития. Саратовский научно-медицинский журнал. 2011. № 7 (2). С. 513-517.

42 Галактионова М. Ю., Маисеенко Д. А., Капитонов В. Ф., Шурова О. А., Павлов А. В. Влияние анемии беременных на раннюю адаптацию новорожденных детей. Российский вестник перинатологии и педиатрии. 2016. № 6 (61). С. 49-53. DOI 10.21508/1027-4065-2016-61-6-49-53.

43 Аушева Ф. Х., Летифов Г. М. Развитие почек и процессы свободнорадикального окисления у новорожденных и детей раннего возраста, рожденных у матерей с неблагоприятным течением беременности. Педиатрия. 2007. № 86 (6). C. $15-20$.

${ }^{44}$ Sabina S., Iftequar S., Zaheer Z., Khan M. M., Khan S. An overview of anemia in pregnancy. Journal of innovations in pharmaceuticals and biological sciences. 2015. № 2 (2). P. 144-151.

${ }^{45}$ Drake K. A., Sauerbry M. J., Blohowiak S. E., Repyak K. S., Kling P. J. Iron deficiency and renal development in the newborn rat. Pediatric research. 2009. № 66. P. 619-624. DOI 10.1203/PDR.0b013e3181be79c2.

${ }^{46}$ Lisle S. J. M., Lewis R. M., Petry C. J., Ozanne S. E., Hales C. N., Forhead A. J. Effect of maternal iron restriction during pregnancy on renal morphology in the adult rat offspring. Br J Nutr. 2003. № 90. P. 33-39. DOI 10.1079/bjn2003881.

47 Махтин Б. И. Функциональная морфология плаценты и почек плодов при неосложненной беременности и гестозах : автореф. дис. ... канд. мед. наук : 14.00.23 ; Иркутский государственный медицинский институт. Иркутск, 1995. 19 с. 
ПЕ та супутня їй перинатальна гіпоксія характеризується залученням до патологічного процесу одночасно гломерулярного й канальцевого апарату нирок недоношених новонароджених. Ураження гломерулярного апарату, що проявляється зниженням швидкості клубочкової фільтрації, набряковим синдромом, підвищенням концентрації креатиніну, має короткочасний характер і нормалізується на тлі проведеної терапії. Високий рівень у сечі молекули ушкодження нирок (kidney injury molecule-1) і ліпокаліну-2 3 перших днів постнатального періоду, що зберігається до 10 доби життя, свідчить про стійкість ураження тубулярного апарату нирок ${ }^{48}$.

Патологія матері, обтяжений акушерсько-гінекологічний анамнез $\epsilon$ причиною порушення уродинаміки в плодів і одним 3 факторів розвитку інфекцій ОСВС ${ }^{49}$.

Артеріальна гіпертензія матері, яка ускладнює перебіг вагітності, призводить до зменшення площі й кількості гломерул ${ }^{50}$. Морфологічний стан нирок плодів і новонароджених залежить від походження артеріальної гіпертензії у матері. Артеріальна гіпертензія у матері, обумовлена розвитком ПЕ, спричиняє збільшення відносної маси нирок і виступає в ролі фактора, що викликає прискорення процесів диференціювання нефрогенної тканини. Однак артеріальна гіпертензія в матері у зв'язку 3 наявністю гіпертонічної хвороби уповільнює та перекручує процес розвитку нирок ${ }^{51}$.

Цукровий діабет матері призводить до розвитку в потомства вроджених вад розвитку ОСВС ${ }^{52}$.

${ }^{48}$ Панахова Н. Ф., Гасанов С. Ш., Ахундова А. А., Алескерова С. М., Полухова А. А. Функциональная характеристика почек недоношенных новорожденных, родившихся у матерей с преэклампсией. Российский вестник перинатологии и педиатрии. 2014. № 3. С. $57-62$.

${ }^{49}$ Чехонацкая М. Л., Хрипунова Г. И., Попков В. М., Бухарова Л. А., Дерюгина Л. А., Василевич Л. К. Инфекции мочевой системы новорожденных: особенности уродинамики нижних мочевых путей в периоде внутриутробного развития. Инновационные технологии медицины XXI века : материалы Всероссийского научного форума, г. Москва, 23-26 мая 2006 года. Москва, 2006. с. 231-233.

${ }^{50}$ Jurado S. R. Effects of the maternal hypertension in renal development in offspring of rats. Journal of Clinical \& Experimental Cardiology. $2014 . \quad № 5$ (4). DOI : 10.4172/2155-9880.1000306.

${ }^{51}$ Мезенцев А. А. Патоморфология почек и клубочковой зоны надпочечников у плодов и новорожденных от матерей с артериальной гипертензией : автореф. дис. ... канд. мед. наук ; Харьковская медицинская академия. Харьков, 1991. 17 с.

${ }^{52}$ Hei M. Y., Yi Z. W. Environmental factors for the development of fetal urinary malformations. World J Pediatr. 2014. № 10 (1). P. 17-23. DOI 10.1007/s12519-0140449-1. 
Наявність у матері ПЕ, цукрового діабету I типу, хронічного гломерулонефриту чинить шкідливу дію на нирки плодів, яка має неспецифічний характер і проявляється зниженням відносної маси нирок; уповільненням темпів диференціювання нефрогенної тканини, що характеризується наявністю великої кількості ембріональних клубочків; порушенням ембріогенезу нирок у вигляді вогнищевих дисплазій i гломерулопатій 3 проліферативнофібропластичними змінами й фіксацією імунних комплексів на гломерулярних базальних мембранах, у мезангіумі, судинних клубочках, базальних мембранах артерій нирок; активацією колагеноутворення. При ПЕ вищеописані зміни $\epsilon$ найменш вираженими, до складу імунних комплексів входять IgG i $\mathrm{C}_{3}$-фракція комплементу. Під час цукрового діабету I типу ці зміни зустрічаються частіше, більш виражені, у складі імунних комплексів переважають $\operatorname{IgA}, \operatorname{IgG}$ і $\mathrm{C}_{3}$-фракція комплементу. При хронічному гломерулонефриті ці зміни є максимальними, до складу імунних комплексів входять $\operatorname{IgA}, \operatorname{IgM}, \operatorname{IgG}, \mathrm{C}_{3}$-фракція комплементу ${ }^{53}$.

У переліку екстрагенітальної та генітальної патології у вагітних і породіль частими $\epsilon$ хронічні інфекційно-запальні захворювання дихальних шляхів, шлунково-кишкового тракту, сечостатевої системи і таке інше. Серед останніх найбільш часто в патологічний процес залучаються ОСВС та органи статевої системи ${ }^{54}$. Хронічні інфекційно-запальні захворювання в організмі вагітної жінки $€$ причиною розвитку фетоплацентарної недостатності, інфікування плода 3 гострим перебігом інфекції або тривалою персистенцією збудника 3 формуванням латентного чи хронічного інфекційного процесу $^{55}$. Відмічено, що генералізований інфекційний процес може бути причиною гострого ушкодження нирок у новонароджених ${ }^{56}$.

Наявність гестаційного пієлонефриту, як і загострення хронічного, супроводжується запальними змінами в плаценті, розвитком

${ }^{53}$ Наумова О. В. Морфофункціональний стан нирок плодів від матерів 3 пізнім гестозом, цукровим діабетом I типу та хронічним гломерулонефритом в умовах Харківського регіону : автореф. дис. ... канд. мед. наук : 14.03.02. Харків, 1999. 23 с.

54 Сергиенко Е. И. Воспалительные заболевания кишечника и беременность. Сучасна гастроентерологія. 2011. № 6 (62). С. 99-105.

${ }_{55}$ Макацария А. Д., Бицадзе В. О., Хизроева Д. Х., Хамани И. В. Плацентарная недостаточность при осложненной беременности и возможности применения дипиридамола. Акушерство, гинекология и репродукиия. 2016. № 4. С. 72-82.

56 Володин Н. Н. Неонатология. Национальное руководство. Москва : ГЭОТАРМедиа, 2013. 896 с. 
внутрішньоутробного інфікування та проявами ендогенної інтоксикації 3 гіпоксичним і токсичним ураженням нирок плода ${ }^{57}$.

Інфекційні захворювання статевих органів у матері в нирках у новонароджених призводять до розвитку дистрофії епітелію канальців аж до розвитку вогнищ некрозу епітелію канальців і навколишньої строми $^{58}$.

Бактеріальний вагіноз у вагітних $є$ причиною розвитку порушень уродинаміки нижніх сечових шляхів плода й змін 3 боку верхніх сечових шляхів ${ }^{59}$.

Таким чином, проведений аналіз даних літератури свідчить про те, що захворювання матері й ускладнення, що виникають на їх тлі під час перебігу вагітностей та пологів, $\epsilon$ ушкоджувальним фактором для ОСВС плодів і новонароджених. Проаналізовані публікації вітчизняних i зарубіжних вчених, присвячені патології ОСВС плодів i новонароджених від матерів з ускладненою вагітністю, мають часом суперечливі дані, несистематизовані, в більшості випадків клінічно спрямовані, не підтверджені сучасними морфологічними методами дослідження. Крім того, в публікаціях дослідники приділяють увагу вивченню впливу патології матері на будь-який один орган сечовидільної системи плода або новонародженого (у більшості випадків на нирки), а не комплексному вивченню всіх органів цієї системи дитини. Патологія матері, ускладнення під час перебігу вагітностей та пологів супроводжуються розвитком і впливом на ОСВС плодів і новонароджених ХВГ, гострої інтранатальної гіпоксії, гострої постнатальної гіпоксії (далі - ГПГ), а часом і змішаної гіпоксії (далі - ЗГ), проте в літературі переважно є дані щодо впливу ХВГ в більшості випадків на нирки плодів і новонароджених. У літературі відсутні комплексні морфологічні дослідження щодо вивчення впливу ПЕ і ЗДА матері різних ступенів тяжкості, хронічних інфекційнозапальних захворювань материнського організму з ідентифікованим збудником на морфо-функціональні особливості нирок, сечоводів,

57 Панова Л. Д., Ахмадеева Э. Н. Патология почек в системе мать-плодноворожденный. Медищинский вестник Башкортостана. 2007. № 2 (1). С. 37-41.

Знаменська Т.К., Жданович Р. І., Килимник Т. М., Журавель А. О., Луценко Т. М., Дзядик Т. В. Патоморфологічні особливості внутрішніх органів новонароджених від матерів з інфекцією статевих органів. Неонатологія, хірургія та перинатальна медицина. 2011. № I (2). С. 118-120.

59 Василевич Р.К. Особенности мочевыделительной функции плода при бактериальном вагинозе у беременных : автореф. дис. ... канд. мед. наук : 14.00.40, 14.00 .01 ; Саратовский государственный медицинский университет. Саратов, 2009. $26 \mathrm{c}$. 
сечового міхура плодів i новонароджених, результати яких, беззаперечно, мали б велике науково-практичне значення.

2. Особливості морфо-функціонального стану нирок, сечоводів, сечового міхура плодів та новонароджених, що розвивалися в умовах експериментальних гострої постнатальної, хронічної внутрішньоутробної та змішаної гіпоксій, експериментального материнського підгострого абдомінального ешеріхіозного інфекційно-запального процесу

В умовах експерименту було виявлено, що ХВГ i ЗГ, яка характеризувалася комбінацією ХВГ і ГПГ, призводили до зменшення маси нирок у плодів та новонароджених щурів, однак ГПГ не впливала на значення цього показника.

У плодів і новонароджених ГПГ, ХВГ і ЗГ призводили до розвитку відповідно мінімальних, помірних та виражених морфо-функціональних змін у капсулах, паренхімі та стромі нирок, структурних елементах усіх шарів сечоводів і сечового міхура. Гіпоксії в нирках первинно ушкоджували паренхіму, де більш виражені зміни відбувалися в канальцевому апараті нефронів і збиральних трубочках, $\mathrm{i}$ судини строми, а в сечоводах та сечовому міхурі - слизову оболонку і судини. При ХВГ структурні зміни в органах наростали у новонароджених порівняно з плодами.

У нирках було відмічено гемодинамічні порушення при ГПГ, ХВГ, ЗГ; дистрофічні, некротичні, десквамативні зміни при ГПГ, ХВГ, ЗГ, а при ХВГ і ЗГ ще й атрофічні зміни ендотеліоцитів судин, епітеліоцитів капсул Боумена, канальців, збиральних трубочок. При ХВГ і ЗГ дегенеративно-десквамативні зміни в епітеліоцитах розвивалися в усіх канальцях i збиральних трубочках, а при ГПГ переважно в проксимальних канальцях. Послідовність залучення різних відділів нефрона в патологічний процес зумовлена їх морфо-функціональною неоднорідністю у зв'язку зі складністю і обсягом виконуваних функцій, послідовністю функціональної діяльності ${ }^{60}$. Зазначені при ГПГ максимальні зміни в проксимальних канальцях, швидше за все, зумовлені тим, що вони характеризуються більшою функціональною активністю, відповідно вони й більш схильні до структурних змін.

ХВГ та ЗГ призводили до розвитку гломерулярних і тубулярних кіст. Також ці види гіпоксій спричиняли затримку процесів

60 Мухамедова С. Г. Хронофизиологические особенности митозов в разных отделах нефрона почки крыс при адаптации к условиям высокогорья Таджикистана : автореф. дис. ... докт. биол. наук : 03.00.13. Москва, 2004. 36 с. 
гломерулогенезу і тубулогенезу, про що свідчило збільшення товщини нефрогенної зони 3 дефіцитом зачатків нефронів, нерівномірне розташування і зменшена абсолютна кількість (далі - АК) ниркових тілець, збільшена відносна кількість (далі - ВК) незрілих ниркових тілець, канальців та протоків.

Зрілі ниркові тільця при ГПГ за формою і розмірами відповідали нормі, а при ХВГ і ЗГ місцями приймали неправильну форму, були 3 малою кількістю капілярних петель або повністю відсутнім судинним клубочком. При ХВГ і ЗГ в гломерулах подекуди було виявлено скупчення ниток фібрину в розширених сечових просторах, початкові прояви гломерулосклерозу у вигляді формування синехій між капілярними петлями й епітелієм капсули Боумена. Деякі ниркові тільця при ХВГ і ЗГ були збільшені в розмірах зі зменшеним просвітом сечового простору та компенсаторною гіперплазією капілярних петель. У ниркових тільцях порівняно з контролем при ХВГ в плодів площа ниркового тільця зменшувалася в 1,2 рази, площа судинного клубочка зменшувалася в 1,4 рази, площа сечового простору не змінювалася, а в новонароджених площа ниркового тільця, судинного клубочка і сечового простору зменшувалася в 1,4 рази; при ЗГ у новонароджених площа ниркового тільця зменшувалася в 1,4 рази, площа судинного клубочка не змінювалася, площа сечового простору зменшувалася в 1,5 рази.

Морфометричні особливості зрілих канальців та збиральних трубочок залежали від виду гіпоксії. При ГПГ зовнішній діаметр канальців та збиральних трубочок не змінювався; діаметр просвіту зменшувався в дистальних прямих канальцях, збиральних трубочках в 1,1 рази, в проксимальних звивистих і прямих, дистальних звивистих канальцях в 1,2 рази, в тонких канальцях не змінювався; висота нефроциту збільшувалася в тонких канальцях в 1,1 рази, в проксимальних звивистих, дистальних прямих і звивистих канальцях, збиральних трубочках в 1,2 рази, в проксимальних прямих канальцях в 1,3 рази. При ХВГ у плодів і новонароджених зовнішній діаметр збільшувався в проксимальних звивистих та прямих канальцях в 1,1 рази, в тонких канальцях в 1,6 i 1,4 рази, в дистальних прямих канальцях в 1,3 і 1,2 рази, в дистальних звивистих канальцях та збиральних трубочках в 1,2 і 1,1 рази; діаметр просвіту збільшувався в проксимальних звивистих канальцях в 1,5 і 1,4 рази, в проксимальних прямих канальцях в 1,8 і 1,5 рази, в тонких канальцях в 3,1 і 2,6 рази, в дистальних прямих канальцях в 1,9 і 1,8 рази, в дистальних звивистих канальцях в 1,5 і 1,3 рази, в збиральних трубочках в 1,3 рази; висота нефроциту зменшувалася в проксимальних звивистих канальцях в 1,2 рази, в проксимальних прямих канальцях в 1,4 і 1,3 рази, в тонких 
канальцях в 1,6 і 1,5 рази, в дистальних прямих канальцях в 1,4 i 1,5 рази, в дистальних звивистих канальцях в 1,4 i 1,2 рази, в збиральних трубочках в 1,4 i 1,3 рази. При ЗГ зовнішній діаметр збільшувався в проксимальних звивистих та прямих, дистальних звивистих канальцях, збиральних трубочках в 1,1 рази, в дистальних прямих канальцях в 1,2 рази, в тонких канальцях в 1,3 рази; діаметр просвіту збільшувався в збиральних трубочках в 1,4 рази, в дистальних звивистих канальцях в 1,6 рази, в проксимальних звивистих канальцях в 1,8 рази, в проксимальних прямих канальцях в 1,9 рази, в дистальних прямих канальцях в 2 рази, в тонких канальцях в 2,7 рази; висота нефроциту зменшувалася в проксимальних звивистих канальцях в 1,5 рази, в збиральних трубочках в 1,7 рази, в проксимальних прямих та дистальних звивистих канальцях в 1,9 рази, в дистальних прямих канальцях в 2,1 рази, в тонких канальцях в 2,2 рази. В канальцевій системі нефронів та збиральних трубочках при ХВГ і ЗГ порівняно 3 ГПГ було виявлено збільшення зовнішнього діаметру, діаметра просвіту і зменшення висоти нефроциту. При ЗГ порівняно з ХВГ зовнішній діаметр не змінювався, діаметр просвіту збільшувався, висота нефроциту зменшувалася.

У стромі нирок плодів і новонароджених, що піддавалися впливу ГПГ, ХВГ, ЗГ, було виявлено переважно клітини фібробластичного ряду й імунні клітини. Ця клітинна інфільтрація наростала порівняно 3 контролем і була мінімальною при ГПГ, помірною при ХВГ і вираженою при ЗГ. ГПГ не впливала на АК CD 3, CD 4, CD 8, CD 20-клітин, збільшувала AK CD 68-клітин. ХВГ та ЗГ спричиняли зменшення АK CD 3, CD 4, CD 8, CD 20-клітин, збільшення AK CD 68-клітин. При ЗГ порівняно з ХВГ АК СD 3, CD 4, CD 8, CD 20-клітин не змінювалася, однак АК CD 68-клітин збільшувалася. Максимальною АК CD 68-клітин була при ЗГ, мінімальною при ГПГ і помірною при ХВГ.

У новонароджених при ГПГ ПО ниркових тілець, канальців $\mathrm{i}$ строми не змінювалися порівняно 3 контролем, однак у плодів i новонароджених при ХВГ і у новонароджених при ЗГ в корі ПО ниркових тілець, канальців зменшувалися, ПО строми збільшувався, а в мозковій речовині ПО канальців зменшувався, ПО строми збільшувався. Збільшення ПО строми в нирках при ХВГ та ЗГ відбувалося за рахунок склерозу, що було відмічено при оглядовій мікроскопії, імуногістохімічному дослідженні (далі - ІГХД) 3 моноклональними антитілами (далі - MКА) до колагенів I, III, IV типів. Склероз також розвивався в стінках судин строми, спричиняючи зменшення товщини м'язового волокна в середній оболонці артеріол i венул, в капсулах, що в жировій капсулі призводило до атрофії 
адипоцитів. У новонароджених при ХВГ порівняно з ЗГ ПО основних структурних компонентів нирок не відрізнялися, однак при ХВГ і ЗГ порівняно з ГПГ ПО ниркових тілець, канальців зменшувалися, ПО строми збільшувався.

Вплив гіпоксій спричиняв у нирках плодів і новонароджених розвиток патогенно індукованого апоптозу, який був мінімальним при ГПГ, помірним при ХВГ і вираженим при ЗГ. Паренхіма була більш схильна до апоптотичних процесів порівняно зі стромою, причому в паренхімі ці процеси були максимальними в тубулярному відділі порівняно з гломерулярним. Тубулярний відділ нефрона, як відомо, поперше, виконує енергоємні транспортні та синтетичні функції, має гірше кровопостачання порівняно з гломерулярним, більш чутливий до ішемічних і гіпоксичних змін; по-друге, він залежить виключно від аеробного окислювального метаболізму й не здатен ефективно переключатися на анаеробний гліколіз в умовах дефіциту кисню ${ }^{61}$.

ГПГ, ХВГ, ЗГ виступали активаторами проліферативних процесів у нирках, які були мінімальними при ГПГ, помірними при ЗГ, вираженими при ХВГ. Проліферативна активність переважала в стромі порівняно 3 паренхімою, причому паренхіматозна проліферативна активність, 3 нашої точки зору, мала компенсаторний характер, а стромальна була обумовлена збільшенням кількості клітин фібробластичного диферону й посиленням їхнього проліферативного потенціалу. Проліферативна активність в паренхімі була максимальною при ХВГ, помірною при ГПГ і мінімальною при ЗГ, а стромальна максимальною при ЗГ, помірною при ХВГ і мінімальною при ГПГ. Таким чином, найбільшою здатністю до збільшення кількості й активації морфо-функціонального стану i, відповідно, проліферативного потенціалу клітин фібробластичного ряду характеризувалася ЗГ, найменшою - ГПГ, а ХВГ займала проміжне положення.

У нирках плодів і новонароджених між процесами апоптозу та проліферації було виявлено дисбаланс, який характеризувався при ГПГ і ХВГ переважанням проліферативних процесів, а при ЗГ - процесів апоптозу.

У сечоводах, сечовому міхурі плодів і новонароджених, що піддавалися впливу ГПГ, ХВГ, ЗГ, були ідентифіковані однотипні зміни. В епітелії слизової оболонки розвивалися набрякові, десквамативні, дегенеративні зміни у вигляді дистрофії, некрозу й атрофії. При ХВГ подекуди в епітеліальному шарі було виявлено

${ }^{61}$ Морозов Ю. А., Марченко Т. В. Патофизиологические аспекты острого почечного повреждения. Почки. 2012. № 2. С. 72-77. 
збільшення кількості шарів, що відображало процеси посиленої проліферації в умовах патології, яка, 3 нашої точки зору, носила компенсаторний характер. При ХВГ і ЗГ було виявлено зменшення кількості характерних для слизової оболонки складок.

У всіх шарах сечоводів, сечового міхура було відмічено гемодинамічні порушення. Останні часто поєднувалися зі змінами в стінках судин, що проявлялися альтерацією і десквамацією ендотеліоцитів, набряком судинних шарів при ГПГ, а при ХВГ і ЗГ ще й склерозом, який призводив до зменшення товщини м'язового волокна середньої оболонки артеріол і венул. Вищезгадані зміни призводили до порушення трофіки органів, розвитку дегенеративних та ішемічних, а при ХВГ і ЗГ ще й склеротичних змін, що проявлялося надмірним вмістом колагенів I, III і IV типів. При ХВГ і ЗГ, враховуючи однаково виражені склеротичні зміни, оптичні щільності імунофлюоресценції колагенів I, III і IV типів не відрізнялися. У м'язовій оболонці при ЗГ склероз призводив до атрофії паренхіми, проте при ХВГ подекуди було виявлено як атрофовані, так і гіпертрофовані м'язові волокна. При ХВГ i ЗГ в м'язовому шарі склеротичні зміни проявлялися порівняно 3 контролем зменшенням ПО паренхіми, товщини м'язового волокна i збільшенням ПО строми, причому між ХВГ і ЗГ ці показники не відрізнялися.

У шарах стінки сечоводів, сечового міхура плодів і новонароджених було виявлено переважно клітини фібробластичного ряду й імунні клітини, причому ця клітинна інфільтрація була мінімальною при ГПГ, помірною при ХВГ і вираженою при ЗГ. Характер місцевих імунних реакцій в сечоводах, сечовому міхурі був подібний до того, що вже описаний в нирках.

У сечоводах, сечовому міхурі плодів, новонароджених, що розвивалися в умовах гіпоксій, товщина епітелію зменшувалася за рахунок розвитку в ньому дегенеративно-десквамативних змін, однак товщина власної пластинки слизової оболонки, підслизової основи, м'язової та адвентиційної оболонок, усієї стінки органів при ГПГ не змінювалася, а при ХВГ і ЗГ збільшувалася у зв'язку з надмірним розвитком сполучної тканини. Товщина епітелію при ГПГ збільшувалася порівняно з ХВГ і ЗГ, а при ЗГ порівняно з ХВГ зменшувалася. При ХВГ порівняно з ЗГ товщина власної пластинки слизової оболонки, підслизової основи, м'язової та адвентиційної оболонок, усієї стінки органів не відрізнялася.

ГПГ, ХВГ, ЗГ активували апоптотичні та проліферативні процеси в сечоводах і сечовому міхурі. При гіпоксіях експресія маркера апоптоза p53 була більш вираженою в перехідному епітелії, ендотеліоцитах 
судин, гладких міоцитах і помірною в імунних клітинах, клітинах фібробластичного ряду. Апоптотична активність була мінімальною при ГПГ, вираженою при ЗГ та помірною при ХВГ. Експресію маркера проліферації Кі-67 при ГПГ і частково при ХВГ було виявлено не тільки в клітинах базального шару перехідного епітелію, як у групі контролю, а також вогнищево й в проміжному шарі, що, з нашої точки зору, мало компенсаторний характер. При ГПГ, ХВГ i ЗГ проліферативна активність знижувалася в епітелії, ендотеліоцитах судин, м'язових i імунних клітинах, підвищувалася в клітинах фібробластичного ряду. При ГПГ проліферативна активність була мінімальною, помірною при ЗГ та вираженою при ХВГ. У сечоводах, сечовому міхурі розвивався дисбаланс між процесами апоптозу та проліферації, який при ГПГ і ХВГ характеризувався переважанням проліферативних процесів, а при ЗГ - процесів апоптозу.

ІГХД 3 віментином, десміном, гладеньком'язовим актином, цитокератинами 18 і 19 виявило важливі факти, що дозволили пояснити механізм розвитку склерозу в нирках, сечоводах, сечовому міхурі плодів і новонароджених, які розвивалися в умовах гіпоксій. По-перше, було відмічено, що ГПГ призводила до збільшення кількості та підвищення морфо-функціонального стану клітин фібробластичного ряду, в тому числі й міофібробластів. По-друге, ХВГ і ЗГ призводили не тільки до наростання кількості клітин фібробластичного диферона, в тому числі i міофібробластів, але й до індукції епітеліальномезенхімальної трансформації.

Материнський пролонгований абдомінальний інфекційно-запальний процес, спричинений Escherichia coli, зумовлював подібні, однак більш виражені порівняно з ХВГ, загальнопатологічні процеси в нирках, сечоводах, сечовому міхурі плодів і новонароджених, які наростали від плода до новонародженого.

При материнській інфекції порівняно 3 ХВГ у плодів і новонароджених маса правої та лівої нирки зменшувалася відповідно в 1,2 і 1,3 рази.

Порівняно 3 ХВГ в нирках збільшувалася товщина нефрогенної зони в плодів і новонароджених у 1,1 рази; АК ниркових тілець у плодів i новонароджених не змінювалася; ПО незрілих і зрілих ниркових тілець не змінювалися; ПО ниркових тілець, канальців і строми не змінювалися; в зрілих ниркових тільцях площа ниркового тільця, судинного клубочка, сечового простору не змінювалася; у плодів і новонароджених у зрілих канальцях і збиральних трубочках зовнішній діаметр не змінювався, однак діаметр просвіту збільшувався в проксимальних звивистих канальцях в 1,1 і 1,3 рази, в проксимальних 
прямих, дистальних прямих, дистальних звивистих канальцях, збиральних трубочках в 1,1 i 1,2 рази, в тонких канальцях в 1,2 рази, висота нефроциту зменшувалася в проксимальних звивистих канальцях в 1,2 і 1,5 рази, в проксимальних прямих канальцях в 1,1 i 1,6 рази, в тонких канальцях в 1,1 i 1,9 рази, в дистальних прямих канальцях в 1,2 і 1,7 рази, в дистальних звивистих канальцях в 1,1 і 1,7 рази, в збиральних трубочках в 1,3 і 1,9 рази; розвивалися більш виражені склеротичні зміни, про що свідчило збільшення оптичної щільності імунофлюоресценції колагенів I, III, IV типів та поява в капсулах клубочків, судинних клубочках, базальних мембранах канальців і збиральних трубочок нетипового колагену III типу. У стінках артеріол і венул товщина м'язового волокна середньої оболонки не змінювалася.

У сечоводах, сечовому міхурі плодів i новонароджених, що розвивалися в умовах материнської інфекції, порівняно з ХВГ товщина епітелію зменшувалася у зв'язку з більш вираженими дегенеративнодесквамативними змінами, а товщина власної пластинки слизової оболонки, підслизової основи, м'язової і адвентиційної оболонок, усієї стінки органів збільшувалася за рахунок склерозу, про що свідчили більші значення оптичної щільності імунофлюоресценції колагенів I, III, IV типів; товщина м'язового волокна в більшості випадків у середній оболонці артеріол і венул зменшувалася; в м'язовому шарі ПО паренхіми і строми не змінювалися, а товщина м'язового волокна зменшувалася. Про більш виражений ушкоджуючий вплив материнської інфекції порівняно з ХВГ свідчила відсутність компенсаторних процесів у сечоводах, сечовому міхурі. Наявна в усіх шарах більш виражена порівняно 3 ХВГ клітинна інфільтрація була представлена переважно клітинами фібробластичного ряду й імунними клітинами, серед яких порівняно з контролем зменшувалася AK CD 3, CD 4, CD 8-клітин, збільшувалася AK CD 20, CD 68-клітин, причому порівняно з ХВГ АК CD 68-клітин була більшою.

Материнський інфекційний процес у нирках, сечоводах, сечовому міхурі плодів і новонароджених призводив до активізації апоптозу i проліферації, серед яких превалювали процеси апоптозу, причому порівняно з ХВГ АК р53-клітин збільшувалася, а АК Кі-67-клітин зменшувалася.

ІГХД з епітеліальними (цитокератинами 18 і 19) і мезенхімальними (віментином, десміном, гладеньком'язовим актином) маркерами так само, як і при ХВГ, виявило збільшення кількості та активізацію клітин фібробластичного диферона, в тому числі і міофібробластів, і індукцію епітеліально-мезенхімальної трансформації, однак ці особливості були більш вираженими в плодів i новонароджених, які розвивалися в 
умовах материнської інфекції, чим можна пояснити більш виражені склеротичні зміни в нирках, сечоводах, сечовому міхурі.

Максимально виражені зміни морфо-функціонального стану нирок, сечоводів, сечового міхура плодів, новонароджених при материнській інфекції порівняно з ХВГ можуть бути пов'язані, по-перше, з більш вираженою хронічною плацентарною недостатністю, розвиток якої обумовлений факторами патогенності Escherichia coli (гіалуронідаза, ДНКаза, лецитиназа, біоплівкоутворення, продукція ендотоксину) i, як наслідок, ХВГ. По-друге, з феноменом материнського епігенетичного імунного імпринтингу. Відомо, що будь-який інфекційно-запальний процес в організмі матері призводить до імунних порушень, у тому числі й до продукції антитіл на певний збудник. У дитини можуть формуватися патологічні зміни в ОСВС як за рахунок прямої агресії, обумовленої цими антитілами, так і за рахунок пренатального програмування його імунної системи на підвищену продукцію тих же антитіл, що й у матері ${ }^{62}$.

\section{3. Морфо-функціональний стан нирок, сечоводів, сечового міхура плодів та новонароджених від матерів, вагітність яких ускладнилася прееклампсією та залізодефіцитною анемією різного ступеня тяжкості}

При вивченні аутопсійного матеріалу було відзначено, що ПЕ та ЗДА легкого та середнього ступеня тяжкості не впливали на вираженість дольчатого рельєфу поверхні нирок плодів і новонароджених, однак тяжка ПЕ та ЗДА призводили до вираженої ембріональної дольчатості. АК дольок на поверхні нирок плодів i новонароджених не відрізнялася при всіх ступенях тяжкості материнської ПЕ порівняно з ЗДА.

У плодів і новонароджених жирова та фіброзна капсули нирок при ЗДА матері всіх ступенів тяжкості, ПЕ легкого ступеня тяжкості були без змін, однак при ПЕ середнього та тяжкого ступеня тяжкості було виявлено виражену жирову капсулу. В нирках на розрізі межа між корою та мозковою речовиною при ЗДА та ПЕ легкого й середнього ступеня тяжкості була чіткою, а при тяжкій ЗДА та ПЕ нечіткою.

У капсулах, паренхімі, стромі нирок, структурних елементах усіх шарів сечоводів, сечового міхура плодів і новонароджених ЗДА, ПЕ призводили до морфо-функціональних змін, які були більш виражені

62 Лучанинова В. Н., Погодаева Т. В. Иммунохимический скрининг с целью определения предрасположенности к патологии почек у новорожденных. Нефрология. 2012. № 16 (1). С. 82-88. DOI 10.24884/1561-6274-2012-16-1-82-88. 
при ПЕ, наростали від плода до новонародженого та зі збільшенням ступеня тяжкості патології матері. У нирках ЗДА і ПЕ спричиняли первинне ушкодження паренхіми та судин строми, причому в паренхімі максимальні зміни відмічалися в канальцях і збиральних трубочках, а в сечоводах та сечовому міхурі - слизової оболонки та судин.

У нирках плодів і новонароджених ПЕ, ЗДА призводили до розвитку порушень гемодинаміки; дегенеративних, десквамативних змін епітелію капсул Боумена, канальців і збиральних трубочок, ендотелію капілярів ниркових тілець та судин строми, формування гломерулярних і тубулярних кіст.

ПЕ та ЗДА матері спричиняли у нащадків затримку гломерулогенезу та тубулогенезу, про що свідчило потовщення нефрогенної зони; нерівномірне розташування і зменшення АК ниркових тілець; збільшення ПО незрілих ниркових тілець, канальців, збиральних трубочок i зменшення ПО зрілих ниркових тілець, канальців, збиральних трубочок. Зі збільшенням ступеня тяжкості ПЕ, ЗДА товщина нефрогенної зони збільшувалася, зменшувалася АК ниркових тілець. ПО незрілих ниркових тілець, канальців, збиральних трубочок збільшувалися і зменшувалися ПО зрілих ниркових тілець, канальців, збиральних трубочок з наростанням ступеня тяжкості ПЕ, при тяжкій ЗДА порівняно з ЗДА середнього ступеня тяжкості.

При ПЕ, ЗДА в плодів і новонароджених зрілі ниркові тільця були переважно малих розмірів зі зменшеною кількістю капілярних петель, місцями приймали неправильну форму. При ПЕ подекуди в гломерулах було виявлено некрози окремих капілярних петель. У зрілих гломерулах у плодів і новонароджених площа ниркового тільця, судинного клубочка, сечового простору при ЗДА легкого ступеня тяжкості зменшувалася в $1,2,1,2,1,3$ рази і $1,2,1,1,1,3$ рази, при ЗДА середнього ступеня тяжкості в $1,4,1,3,1,7$ рази і $1,3,1,2,1,6$ рази. При тяжкій ЗДА в плодів і новонароджених площа ниркового тільця, судинного клубочка зменшувалася в 1,7, 3,1 рази і 1,5, 2,9 рази, а площа сечового простору збільшувалася в 1,2 і 1,3 рази. При ПЕ легкого ступеня тяжкості в плодів і новонароджених площа ниркового тільця, судинного клубочка, сечового простору зменшувалася в 1,3, 1,2, 1,4 рази і $1,2,1,2,1,4$ рази. При ПЕ середнього і тяжкого ступеня тяжкості в плодів i новонароджених площа ниркового тільця, судинного клубочка зменшувалася в $1,5,2,9$ рази і $1,4,2,7$ рази, 1,7, 5,5 рази і 1,6, 5,6 рази, а площа сечового простору збільшувалася в 1,4 і 1,4 рази, 1,5 і 1,5 рази. Зі збільшенням ступеня тяжкості при ЗДА площа ниркового тільця і судинного клубочка зменшувалася, площа сечового простору при ЗДА середнього ступеня тяжкості порівняно 
3 легким ступенем зменшувалася, а при тяжкій ЗДА порівняно 3 середнім ступенем збільшувалася; при ПЕ площа ниркового тільця, судинного клубочка зменшувалася, а площа сечового простору збільшувалася.

Морфометричні особливості зрілих відділів канальцевої системи та збиральних трубочок у плодів і новонароджених залежали від виду материнської патології та їі ступеня тяжкості. При ЗДА матері легкого та середнього ступеня тяжкості зовнішній діаметр і діаметр просвіту збільшувалися, висота нефроциту зменшувалася, а при тяжкій ЗДА зовнішній діаметр і висота нефроциту зменшувалися, діаметр просвіту збільшувався. При ПЕ легкого ступеня тяжкості зовнішній діаметр і діаметр просвіту збільшувалися, висота нефроциту зменшувалася, а при ПЕ середнього та тяжкого ступеня тяжкості зовнішній діаметр, висота нефроциту зменшувалися, діаметр просвіту збільшувався.

При ЗДА середнього ступеня тяжкості порівняно з легким ступенем зовнішній діаметр і діаметр просвіту збільшувалися, висота нефроциту зменшувалася; при тяжкій ЗДА порівняно із середнім ступенем тяжкості зовнішній діаметр, діаметр просвіту та висота нефроциту зменшувалися. При середньому ступені тяжкості ПЕ порівняно 3 легким зовнішній діаметр, діаметр просвіту й висота нефроциту зменшувалися, при тяжкій ПЕ порівняно із середнім ступенем тяжкості зовнішній діаметр, висота нефроциту зменшувалися, діаметр просвіту збільшувався.

Про більш виражений ушкоджуючий ефект ПЕ свідчила відсутність компенсаторних процесів у паренхімі нирок, які при ЗДА були представлені гіпертрофією окремих ниркових тілець 3 гіперплазією капілярних петель, гіпертрофією і гіперплазією епітеліоцитів канальців і збиральних трубочок.

У плодів і новонароджених від матерів з ЗДА, ПЕ у капсулах, стромі нирок було виявлено виражену клітинну інфільтрацію, представлену переважно клітинами фібробластичного ряду й імунними клітинами. ЗДА легкого ступеня тяжкості зменшувала AK CD 68-клітин, ЗДА середнього й тяжкого ступеня тяжкості зменшувала АK CD 3, CD 4, CD 8, CD 20-клітин, збільшувала АK CD 68-клітин. ПЕ легкого ступеня тяжкості збільшувала АK СD 3, CD 8, CD 20, CD 68-клітин, зменшувала АK CD 4-клітин; ПЕ середнього й тяжкого ступеня тяжкості збільшувала АК усіх імунних клітин. Зі збільшенням ступеня тяжкості ЗДА зменшувалася АK CD 3, CD 4, CD 8, CD 20-клітин і збільшувалася AK CD 68-клітин. При ПЕ середнього ступеня тяжкості порівняно з легким ступенем збільшувалася АK CD 3, CD 4, CD 20, CD 68-клітин, зменшувалася AK CD 4-клітин, а при тяжкій ПЕ 
порівняно з ПЕ середнього ступеня тяжкості збільшувалася АК усіх імунних клітин.

ПЕ і ЗДА спричиняли надмірну продукцію колагенів I, III, IV типів і розвиток склерозу в нирках нащадків, що проявлялося збільшенням ПО строми й зменшенням ПО ниркових тілець, канальців. Чим більший був ступінь тяжкості ПЕ, ЗДА, тим більше збільшувався ПО строми i зменшувалися ПО ниркових тілець, канальців.

Материнська ПЕ і ЗДА в сечоводах, сечовому міхурі плодів i новонароджених призводили до розвитку однотипних змін, представлених дегенерацією i десквамацією епітелію слизової оболонки, спричиняючи його стоншення, проте в плодів при ЗДА матері легкого ступеня тяжкості товщина його збільшувалася в 1,1 рази за рахунок компенсаторної гіперплазії епітеліоцитів; порушенням гемодинаміки; дегенерацією і десквамацією ендотеліоцитів судин 3 набряком i склерозом судинних шарів; дегенерацією та ішемією паренхіми м'язової оболонки; атрофією i гіпертрофією м'язових волокон при ЗДА та їх атрофією при ПЕ; збільшенням кількості клітин фібробластичного ряду, порушеннями місцевих імунних реакцій, які були подібні до тих, що описані в нирках. Вищезгадана патологія матері в сечоводах, сечовому міхурі плодів i новонароджених спричиняла розвиток склерозу власної пластинки слизової оболонки, підслизової основи, м'язової та адвентиційної оболонок за рахунок надмірної продукції колагенів I, III, IV типів, що призводило до потовщення цих шарів і всієї стінки при ЗДА легкого ступеня тяжкості в 1,1 і 1,2 рази, 1,1 і 1,2 рази, при ЗДА середнього ступеня тяжкості в 1,1 i 1,4 рази, 1,1 і 1,4 рази, при тяжкій ЗДА в 1,2 і 1,5 рази, 1,1 i 1,6 рази, при ПЕ легкого ступеня тяжкості в 1,1 і 1,3 рази, 1,1 і 1,5 рази, при ПЕ середнього ступеня тяжкості в 1,1 і 2 рази, 1,1 і 1,8 рази, при тяжкій ПЕ в 1,3 і 2,7 рази, 1,2 і 2,6 рази. Чим більший був ступінь тяжкості ПЕ, ЗДА, тим більше зменшувалася товщина епітелію, збільшувалася товщина шарів і всієї стінки органів.

У нирках, сечоводах, сечовому міхурі плодів і новонароджених ПЕ і ЗДА матері активізували апоптотичні й проліферативні процеси 3 розвитком між ними дисбалансу. Аналіз імуногістохімічних реакцій з МКА до віментину, десміну, гладеньком'язового актину, цитокератинів 18 і 19 показав, що материнська ЗДА і ПЕ виступали факторами, які активізували клітини фібробластичного ряду, в тому числі й міофібробласти, та індукували епітеліально-мезенхімальну трансформацію, причому ці особливості були більш вираженими при ПЕ порівняно із ЗДА, наростали зі збільшенням ступеня тяжкості патології матері й $з$ віком дитини. 
Порівняльний аналіз результатів дослідження місцевих імунних реакцій в нирках, сечоводах, сечовому міхурі плодів і новонароджених, які розвивалися в умовах ГПГ, ХВГ, ЗГ, материнського підгострого абдомінального ешеріхіозного запального процесу, материнської ЗДА і ПЕ різних ступенів тяжкості, виявив в усіх ситуаціях активізацію макрофагальної системи. Враховуючи локалізацію макрофагів у локусах склерозу, навколо незрілих структур, гломерулярних i тубулярних кіст, було зроблено припущення щодо їх участі в морфогенезі склерозу, кістоутворенні та затримці процесів гломерулогенезу і тубулогенезу.

\section{ВИСНОВКИ}

Проведене комплексне морфологічне дослідження клінічного й експериментального матеріалу дозволило довести на підставі виявлених макроскопічних i мікроскопічних змін ушкоджуючу дію на нирки, сечоводи, сечовий міхур плодів і новонароджених експериментальних гіпоксій (ГПГ, ХВГ, ЗГ), експериментального материнського підгострого абдомінального інфекційно-запального процесу, спричиненого Escherichia coli, материнської ЗДА і ПЕ ${ }^{63}$ (рис. 1).

Вплив вивчених на клінічному й експериментальному матеріалі ушкоджуючих факторів призводив до змін капсул, паренхіматозного й стромально-судинного компонентів нирок, структурних елементів усіх шарів стінки сечоводів i сечового міхура плодів i новонароджених, причому в нирках первинно ушкоджувалася паренхіма органу - водночас більш виражені зміни були виявлені в тубулярному компоненті нефрона порівняно з гломерулярним - i судини строми, а в сечоводах і сечовому міхурі - слизова оболонка і судини. В нирках, сечоводах і сечовому міхурі плодів i новонароджених ушкоджуючі фактори призводили до дистрофічних, некротичних, десквамативних, гемодинамічних змін, активізації процесів апоптозу та проліферації клітинних елементів 3 розвитком між цими процесами дисбалансу, порушень місцевих імунних реакцій. Тривала дія факторів також призводила до розвитку склерозу в нирках, сечоводах і сечовому міхурі плодів і новонароджених, в механізмі розвитку якого була доведена роль епітеліально-мезенхімальної трансформації, i затримки процесів гломерулогенеза і тубулогенеза, формуванню гломерулярних і тубулярних кіст, в механізмі розвитку яких була припущена роль клітин макрофагального ряду.

${ }^{63}$ Мирошниченко М. С. Патологічна анатомія сечовидільної системи плодів та новонароджених від матерів з ускладненою вагітністю : автореф. дис. ... докт. мед. наук : 14.03 .02 ; Харківський національний медичний університет. Харків, 2019. $46 \mathrm{c}$. 

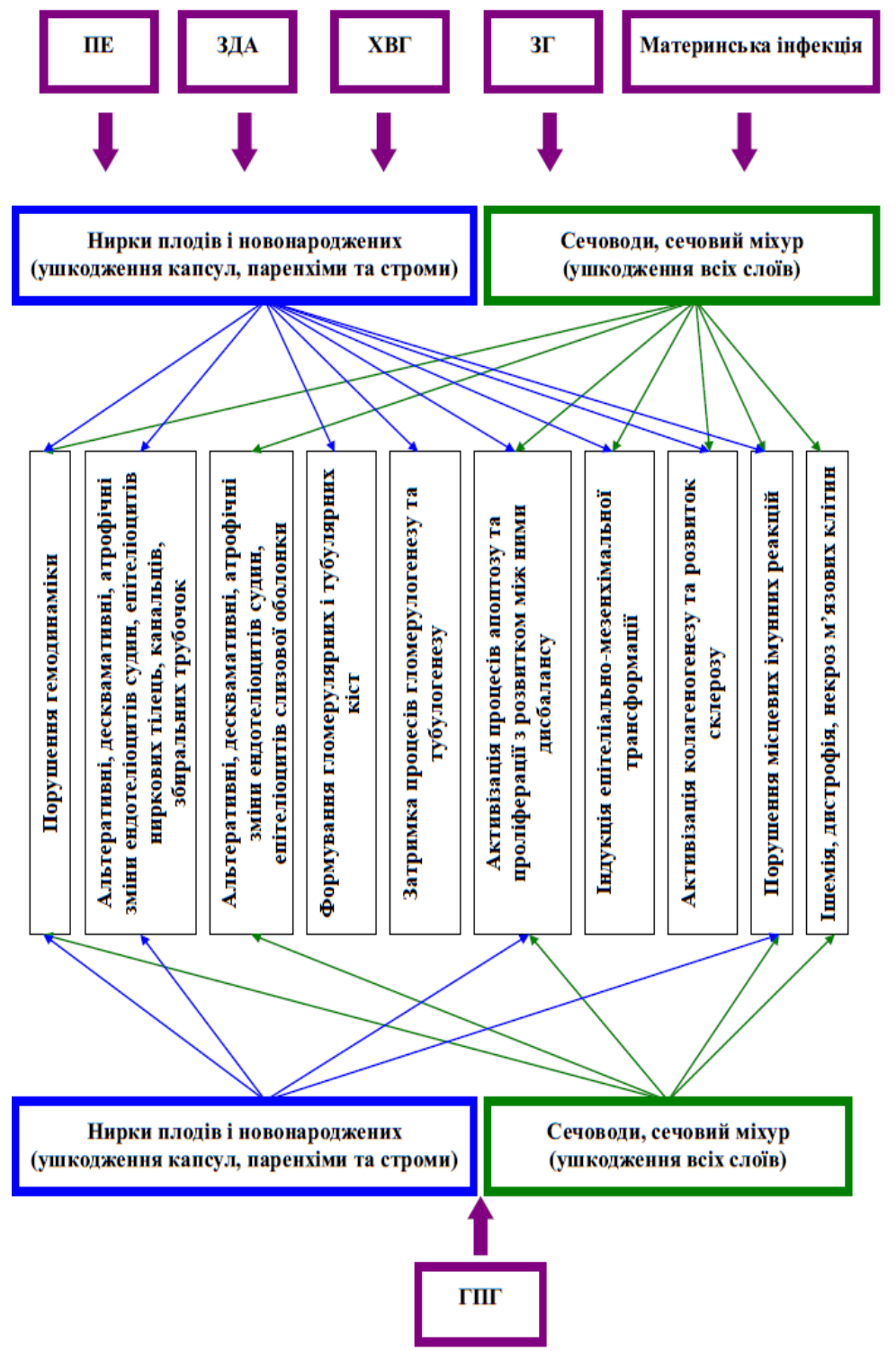

Рис. 1. Основні ушкоджуючі ефекти ПЕ, ЗДА, ГПГ, ХВГ, ЗГ, материнської інфекції на нирки, сечоводи, сечовий міхур плодів і новонароджених 
У плодів і новонароджених, які піддавалися впливу ушкоджуючих факторів, в нирках, сечоводах і сечовому міхурі виявлені порушення місцевих імунних реакцій, і доведена роль епітеліально-мезенхімальної трансформації в розвитку склерозу $є$ доказовою базою для пошуку превентивних i терапевтичних методів впливу на дані загальнопатологічні процеси.

Запропонована гіпотеза щодо участі клітин макрофагального ряду в механізмах затримки процесів гломерулогенеза й тубулогенеза в нирках плодів i новонароджених, які розвивалися в патологічних умовах, $\epsilon$ перспективним напрямком для майбутніх досліджень, доведеність якої дасть можливість терапевтичного впливу на такий клітинний диферон 3 метою прискорення процесів дозрівання гломерулярного і тубулярного компонентів нефрона.

Виявлені морфологічні зміни в нирках, сечоводах і сечовому міхурі плодів і новонароджених, які розвивалися в патологічних умовах, враховуючи єдність структури й функції, призведуть до функціональних змін цих органів у подальшому постнатальному онтогенезі в таких дітей і виникненню в них різної нефроурологічної патології.

Дослідження актуалізує проведення профілактичних заходів серед осіб репродуктивного віку, диктує необхідність проведення якісної прегравідарної підготовки, яка повинна бути спрямована на своєчасне виявлення і лікування генітальної та екстрагенітальної патології в жіночому організмі, в тому числі виявлення і санацію вогнищ інфекції.

Одержані авторами дані щодо органометричних та мікроскопічних характеристик нирок, сечоводів та сечового міхура плодів i новонароджених від матерів 3 фізіологічною вагітністю доповнюють та розширюють сучасну інформаційну базу щодо розвитку й особливостей будови ОСВС плодів і новонароджених та можуть бути використані в практичній роботі патологоанатомами, гістологами й іншими спеціалістами як науково обгрунтовані нормативні дані.

Визначені авторами органометричні, морфологічні характеристики нирок, сечоводів, сечового міхура плодів i новонароджених, що розвивалися в умовах ПЕ, ЗДА, ГПГ, ХВГ та ЗГ, материнського абдомінального пролонгованого інфекційно-запального процесу, спричиненого Escherichia coli, рекомендовано брати за основу лікарямпатологоанатомам у своїй практичній діяльності для об'єктивізації і поліпшення діагностики патологічних станів ОСВС у плодів та новонароджених. 


\section{АНОТАЦІЯ}

Патологія органів сечовидільної системи (ОСВС) дитячого населення України $\epsilon$ серйозною i значимою проблемою сучасної педіатрії. Захворювання матері, ускладнення під час вагітностей та пологів виступають основними факторами, що призводять до ушкодження ОСВС плодів та новонароджених. Проведене авторами комплексне морфологічне дослідження клінічного й експериментального матеріалу дозволило довести на підставі виявлених макроскопічних і мікроскопічних змін ушкоджуючу дію на нирки, сечоводи, сечовий міхур плодів i новонароджених гострої постнатальної гіпоксії (ГПГ), хронічної внутрішньоутробної гіпоксії (ХВГ), змішаної гіпоксії (ЗГ), експериментального материнського підгострого абдомінального інфекційно-запального процесу, спричиненого Escherichia coli, залізодефіцитної анемії (ЗДА) та прееклампсії (ПЕ) різних ступенів тяжкості. Виявлені морфологічні зміни в нирках, сечоводах, сечовому міхурі плодів і новонароджених, які розвивалися в патологічних умовах, враховуючи єдність структури й функції, призведуть до функціональних змін цих органів у подальшому постнатальному онтогенезі таких дітей і виникненню в них різної нефроурологічної патології.

\section{ЛITEPATУРA}

1. Дудіна О. О., Терещенко А. В. Ситуаційний аналіз стану здоров'я дитячого населення. Вісник соиіальної гігієни та організації охорони здоров'я Украӥни. 2014. № 2 (60). С. 49-57.

2. Щорічна доповідь про стан здоров'я населення, санітарноепідемічну ситуацію та результати діяльності системи охорони здоров'я України. 2013 рік / Український інститут стратегічних досліджень Міністерства охорони здоров'я України ; за ред. О. С. Мусія та ін. Київ, 2014. $438 \mathrm{c}$.

3. Щорічна доповідь про стан здоров'я населення, санітарноепідемічну ситуацію та результати діяльності системи охорони здоров'я України. 2014 рік / Український інститут стратегічних досліджень Міністерства охорони здоров'я України ; за ред. О. М. Квіташвілі та ін. Київ, 2015. 460 с.

4. Щорічна доповідь про стан здоров'я населення, санітарноепідемічну ситуацію та результати діяльності системи охорони здоров'я України. 2015 рік / Український інститут стратегічних досліджень Міністерства охорони здоров'я України ; за ред. В. В. Шафранського. Київ, 2016. 452 с. 
5. Щорічна доповідь про стан здоров'я населення, санітарноепідемічну ситуацію та результати діяльності системи охорони здоров'я України. 2016 рік / Український інститут стратегічних досліджень Міністерства охорони здоров'я України ; за ред. П. С. Мельника та ін. Київ : Коломіцин В. Ю., 2017. 516 с.

6. Антипкін Ю. Г., Волосовець О. П., Майданник В. Г., Березенко В. С., Моісеєнко Р. О., Виговська О.В. та ін. Стан здоров'я дитячого населення - майбутнє країни (частина 1). Здоровье ребенка. 2018. № 13 (1). C. 1-11. DOI: 10.22141/2224-0551.13.1.2018.127059.

7. Безрук В. В. Нефрологічна патологія у дітей підліткового віку Чернівецької області. Вісник проблем біології $і$ медицини. 2014. № 3 (1/110). C. 34-37.

8. Чугунова О. Л., Панова Л. Д. Факторы риска и диагностика заболеваний органов мочевой системы у новорожденных детей. Российский вестник перинатологии и педиатрии. 2010. № 1. С. 12-20.

9. Ingelfinger J. R., Kalantar-Zadeh K., Schaefer F. World kidney day 2016: averting the legacy of kidney disease - focus on childhood. Pediatr Nephrol. 2016. № 31 (3). P. 343-348. DOI: 10.1111/jorc.12148.

10. Островский И. М., Прохоров Е. В., Нарижный М. Ю. Здоровье детей по результатам анкетирования родителей. Российский вестник перинатологии и педиатрии. 2017. № 62 (3). С. 105-111. DOI: 10.21508/1027-4065-2017-62-3-105-111.

11. Иванова И. Е., Яшина Е. В. Особенности мочевого синдрома у грудных детей, перенесших гипоксически-ишемические состояния в перинатальнои периоде. Здравоохранение Чувашии. 2012. № 3. C. 34-38.

12. Панова Л. Д., Ахмадеева Э. Н. Патология почек в системе матьплод-новорожденный. Медииинский вестник Башкортостана. 2007. № 2 (1). С. 37-41.

13. Иванов Д. О., Петренко Ю. В., Шемякина О. О., Фот А. Ю. Анализ антенатальных факторов риска формирования врожденных пороков внутренних органов у детей. Трансляционная медицина. 2012. № 1 (12). С. 61-68.

14. Генералова Г. А., Алимова Е. Ю., Якунина Н. А. Роль эпигенетических факторов в формировании аномалий органов мочевой системы у детей. Современные технологии в педиатрии и детской хирургии : материалы IV Российского конгресса. Москва, 2005. с. 183.

15. Зеленцова В. Л., Шилко В. И., Медведева С. Ю. Морфологические особенности почек у плодов и новорожденных, перенесших гипоксию. Архив патологии. 2003. № 6. С. 40-44. 
16. Попов С. В., Облазницкий В. Н. Особенности нарушения функций мочевыделительной системы $\mathrm{y}$ новорожденных с гипоксическим поражением ЦНС тяжелой степени. Вісник СумДУ. Серія “Медиџина". 2008. № 2 (2). C. 88-91.

17. Аушева Ф. Х., Летифов Г. М. Развитие почек и процессы свободнорадикального окисления у новорожденных и детей раннего возраста, рожденных у матерей с неблагоприятным течением беременности. Педиатрия. 2007. № 86 (6). С. 15-20.

18. Зербіно Д. Д., Багрій М. М., Дядик О. О. Судинна патологія нирок. Вінниця : Нова книга, 2015. 456 с.

19. Hei M. Y., Yi Z. W. Environmental factors for the development of fetal urinary malformations. World J Pediatr. 2014. № 10 (1). P. 17-23. DOI: 10.1007/s12519-014-0449-1.

20. Tang J., Zhu Z., Xia S., Li N., Chen N., Gao Q. et al. Chronic hypoxia in pregnancy affected vascular tone of renal interlobar arteries in the offspring. Scientific Reports. 2015. № 5 (9723). DOI: 10.1038/srep09723.

21. Яблонь О. С., Задорожна Т. Д., Саврун Т. І., Холод Л. П. Клінікоморфологічні паралелі у дослідженні нирок недоношених новонароджених, які перенесли перинатальну гіпоксію. Современная педиатрия. 2013. № 8 (56). С. 145-149.

22. Лук'яненко Н. С., Гнатенко О. З., Кенс К. А., Ковалів І. Б., Кеч Н. Р. Фактори формування хронічного захворювання нирок у дітей раннього віку з природженими вадами розвитку нирок. Украӥнський журнал нефрології та діалізу. 2012. № 3 (35/1). С. 51-55.

23. Чугунова О. Л., Шумихина М. В., Думова С. В. Современные представления об инфекции органов мочевой системы у новорожденных и детей раннего возраста. Эффективная фармакотерапия. 2013. № 42. С. 38-47.

24. Халецкая О. В., Козлова Е. М., Шунькина Г. Л., Булдынская Л. И., Шкалова Л. В. Полиорганность поражения у новорожденных при тяжелой гипоксии. Медицинский альманах. 2007. № 1. С. 84-86.

25. Нурмагамбетова Б. К. Особенности течения полиорганной недостаточности у доношенных новорожденных. Денсаулык сактауды дамытуу журнальы. 2012. № 1 (2). С. 55-58.

26. Годованець Ю. Д., Бабінцева А. Г., Нікорич С. І. Гостре пошкодження нирок у новонароджених : невирішені питання діагностики та стратифікації ступеня тяжкості патології. Неонатологія, хірургія та перинатальна медищина. 2014. № IV (3/13). C. 89-94.

27. Аборин С. В., Прилепина М. А. Семиотика острого повреждения почек у недоношенных детей. Национальная ассоциация ученых (Медицинские науки). 2015. № IX (14). С. 100-103. 
28. Плотников Е. Ю., Силачев Д. Н., Павленко Т. А., Павлова В. С., Крючко Д. С., Зубков В. В., Зоров Д. Б., Сухих Г. Т. Острое повреждение почек у новорожденных. От эксперимента к клинической практике. Неонатология: новости, мнения, обучение. 2017. № 4. C. $58-63$.

29. Володин Н. Н. Неонатология. Национальное руководство. Москва : ГЭОТАР-Медиа, 2013. 896 с.

30. Гельдт В. Г., Кузовлева Г. И. Диагностика пороков мочевыделительной системы у новорожденных и грудных детей. Педиатрия. 2006. № 1. С. 87-94.

31. Даминова М. А., Сафина А. И., Хамзина Г. А. Морфофункциональные особенности органов мочевой системы у детей, родившихся недоношенными и маловесными. Вестник современной клинической медииины. 2013. № 6 (2). С. 79-86.

32. Белоусова Т. В., Андрюшина И. В. Задержка внутриутробного развития и ее влияние на состояние здоровья детей в последующие периоды жизни. Возможности нутритивной коррекции. Bonpocbl современной педиатрии. 2015. № 14 (1). С. 23-30. DOI: 10.15690/vsp.v14i1.1259.

33. Сисоєнко О. П. Морфологічна характеристика нирок плоду в строку гестації 20-27 тижнів при затримці внутрішньоутробного розвитку : автореф. дис. ... канд. мед. наук : 14.03 .02 ; Луганський державний медичний університет. Луганськ, 2003. 19 с.

34. Wang Y. P., Chen X., Zhang Z. K., Cui H. Y., Wang P., Wang Y. Effects of a restricted fetal growth environment on human kidney morphology, cell apoptosis and gene expression. J Renin Angiotensin Aldosterone Syst. 2015. № $16 \quad$ (4). P. 1028-1035. DOI: $10.1177 / 1470320314543808$.

35. Глыбочко П. В., Чехонацкая М. Л., Пискунова Л. В. Состояние уродинамики нижних мочевых путей плода при задержке внутриутробного развития. Саратовский научно-медицинский журнал. 2011. № 7 (2). С. 513-517.

36. Галактионова М. Ю., Маисеенко Д. А., Капитонов В. Ф., Шурова О. А., Павлов А. В. Влияние анемии беременных на раннюю адаптацию новорожденных детей. Российский вестник перинатологии u педиатрии. 2016. № 6 (61). C. 49-53. DOI: 10.21508/1027-4065-201661-6-49-53.

37. Sabina S., Iftequar S., Zaheer Z., Khan M. M., Khan S. An overview of anemia in pregnancy. Journal of innovations in pharmaceuticals and biological sciences. 2015. № 2 (2). P. 144-151. 
38. Drake K. A., Sauerbry M. J., Blohowiak S. E., Repyak K. S., Kling P. J. Iron deficiency and renal development in the newborn rat. Pediatric research. 2009. № 66. P. 619-624. DOI: 10.1203/PDR.0b013e3181be79c2.

39. Lisle S. J. M., Lewis R. M., Petry C. J., Ozanne S. E., Hales C. N., Forhead A. J. Effect of maternal iron restriction during pregnancy on renal morphology in the adult rat offspring. Br J Nutr. 2003. № 90. P. 33-39. DOI: $10.1079 /$ bjn2003881.

40. Махтин Б. И. Функциональная морфология плаценты и почек плодов при неосложненной беременности и гестозах : автореф. дис. ... канд. мед. наук : 14.00.23 ; Иркутский государственный медицинский институт. Иркутск, 1995. 19 с.

41. Панахова Н. Ф., Гасанов С. Ш., Ахундова А. А., Алескерова С. М., Полухова А. А. Функциональная характеристика почек недоношенных новорожденных, родившихся у матерей с преэклампсией. Российский вестник перинатологии и педиатрии. 2014. № 3. С. 57-62.

42. Чехонацкая М. Л., Хрипунова Г. И., Попков В. М., Бухарова Л. А., Дерюгина Л. А., Василевич Л. К. Инфекции мочевой системы новорожденных: особенности уродинамики нижних мочевых путей в периоде внутриутробного развития. Инновачионные технологии медицины XXI века : материалы Всероссийского научного форума, г. Москва, 23-26 мая 2006 года. Москва, 2006. с. 231-233.

43. Jurado S. R. Effects of the maternal hypertension in renal development in offspring of rats. Journal of Clinical \& Experimental Cardiology. 2014. № 5 (4). DOI:10.4172/2155-9880.1000306.

44. Мезенцев А. А. Патоморфология почек и клубочковой зоны надпочечников у плодов и новорожденных от матерей с артериальной гипертензией : автореф. дис. ... канд. мед. наук ; Харьковская медицинская академия. Харьков, 1991. 17 с.

45. Наумова О. В. Морфофункціональний стан нирок плодів від матерів з пізнім гестозом, цукровим діабетом I типу та хронічним гломерулонефритом в умовах Харківського регіону : автореф. дис. ... канд. мед. наук : 14.03.02. Харків, 1999. 23 с.

46. Сергиенко Е. И. Воспалительные заболевания кишечника и беременность. Сучасна гастроентерологія. 2011. № 6 (62). С. 99-105.

47. Макацария А. Д., Бицадзе В. О., Хизроева Д. Х., Хамани И. В. Плацентарная недостаточность при осложненной беременности и возможности применения дипиридамола. Акушерство, гинекология $u$ репродукциия. 2016. № 4. С. 72-82.

48. Знаменська Т. К., Жданович Р. І., Килимник Т. М., Журавель А. О., Луценко Т. М., Дзядик Т. В. Патоморфологічні особливості внутрішніх органів новонароджених від матерів 3 інфекцією статевих органів. 
Неонатологія, хірургія та перинатальна медицина. 2011. № (2). С. $118-120$.

49. Василевич Р. К. Особенности мочевыделительной функции плода при бактериальном вагинозе у беременных : автореф. дис. ... канд. мед. наук : $14.00 .40,14.00 .01$; Саратовский государственный медицинский университет. Саратов, 2009. 26 с.

50. Мухамедова С. Г. Хронофизиологические особенности митозов в разных отделах нефрона почки крыс при адаптации к условиям высокогорья Таджикистана : автореф. дис. ... докт. биол. наук : 03.00.13. Москва, 2004. 36 с.

51. Морозов Ю. А., Марченко Т. В. Патофизиологические аспекты острого почечного повреждения. Почки. 2012. № 2. С. 72-77.

52. Лучанинова В. Н., Погодаева Т. В. Иммунохимический скрининг с целью определения предрасположенности к патологии почек у новорожденных. Нефрология. 2012. № 16 (1). С. 82-88. DOI: 10.24884/1561-6274-2012-16-1-82-88.

53. Мирошниченко М. С. Патологічна анатомія сечовидільної системи плодів та новонароджених від матерів 3 ускладненою вагітністю : автореф. дис. ... докт. мед. наук : 14.03.02 ; Харківський національний медичний університет. Харків, 2019. 46 с.

\section{Information about authors: Myroshnychenko M. S., \\ Doctor of Medical Sciences,} Associate Professor of the Department of Pathological Anatomy Kharkiv National Medical University 4, Nauky Avenue, Kharkiv, 61022, Ukraine

Kapustnyk N. V., Candidate of Medical Sciences, Associate Professor of the Department of Obstetrics and Gynecology № 1

Kharkiv National Medical University 4, Nauky Avenue, Kharkiv, 61022, Ukraine Head of the Gynecological Department № 2 Public nonprofit organization of the Kharkiv District Council

"Regional Clinical Perinatal Centre" 4, Marshal Malinovsky st., Kharkiv, 61000, Ukraine 